\title{
Changing Faces Competition. Mobilizing Citizens to Reclaim Public Spaces in Nairobi
}

Anna Tehlova

Public Space Network

partners@publicspacenetwork.org

\begin{abstract}
Statistics show that urban green public spaces deteriorate globally. In African cities, where the urbanization rates are the highest in the world, public spaces quickly disappear under layers of garbage or are grabbed. For public authorities having to deal with other pressing socio-economic challenges in the context of outdated regulations, insufficient capacity and resources and wide-spread corruption, public spaces are not a priority. However, the research worldwide has demonstrated the potential of public spaces to become the key catalyst of socio-economic growth given their environmental, economic and social benefits that are however largely ignored by public authorities and the general public in African cities. This article suggests a citizen-driven public space upgrading movement can address these challenges and presents a gamification approach for citizen mobilization and raising awareness: The Changing Faces Competition that has been piloted by Nairobi-based organizations Dandora Transformation League and Public Space Network.
\end{abstract}

Keywords: public spaces, African cities, placemaking, community ownership, gamification

To cite this article:

Tehlova, A. (2019). Changing Faces Competition. Mobilizing Citizens to Reclaim Public Spaces in Nairobi, The Journal of Public Space, 4(3), 6I-86, DOI 10.3289I/jps.v4i3.I22I

This article has been double blind peer reviewed and accepted for publication in The Journal of Public Space. This work is licensed under a Creative Commons Attribution - Non Commercial 4.0 International License https://creativecommons.org/licenses/by-nc/4.0/ 


\section{Introduction}

Formerly known as 'the Green City in the Sun', Nairobi used to be praised for its green parks, forests and even a national park within the city limits. However, the aerial map of Nairobi (Figure I) reveals significant disparities in the green coverage between the eastern and western parts of the city. An overall divergence in quality of life within the city is reflected by the segregated urban pattern, inequalities in population density, and access to green areas. Despite having few large green parks (such as Uhuru Park, Arboretum or Karura forest) most of Nairobi public spaces and especially small-scale open spaces in residential areas tend to be completely neglected, covered by the dumped garbage or disappearing under the common threat of land-grabbing.

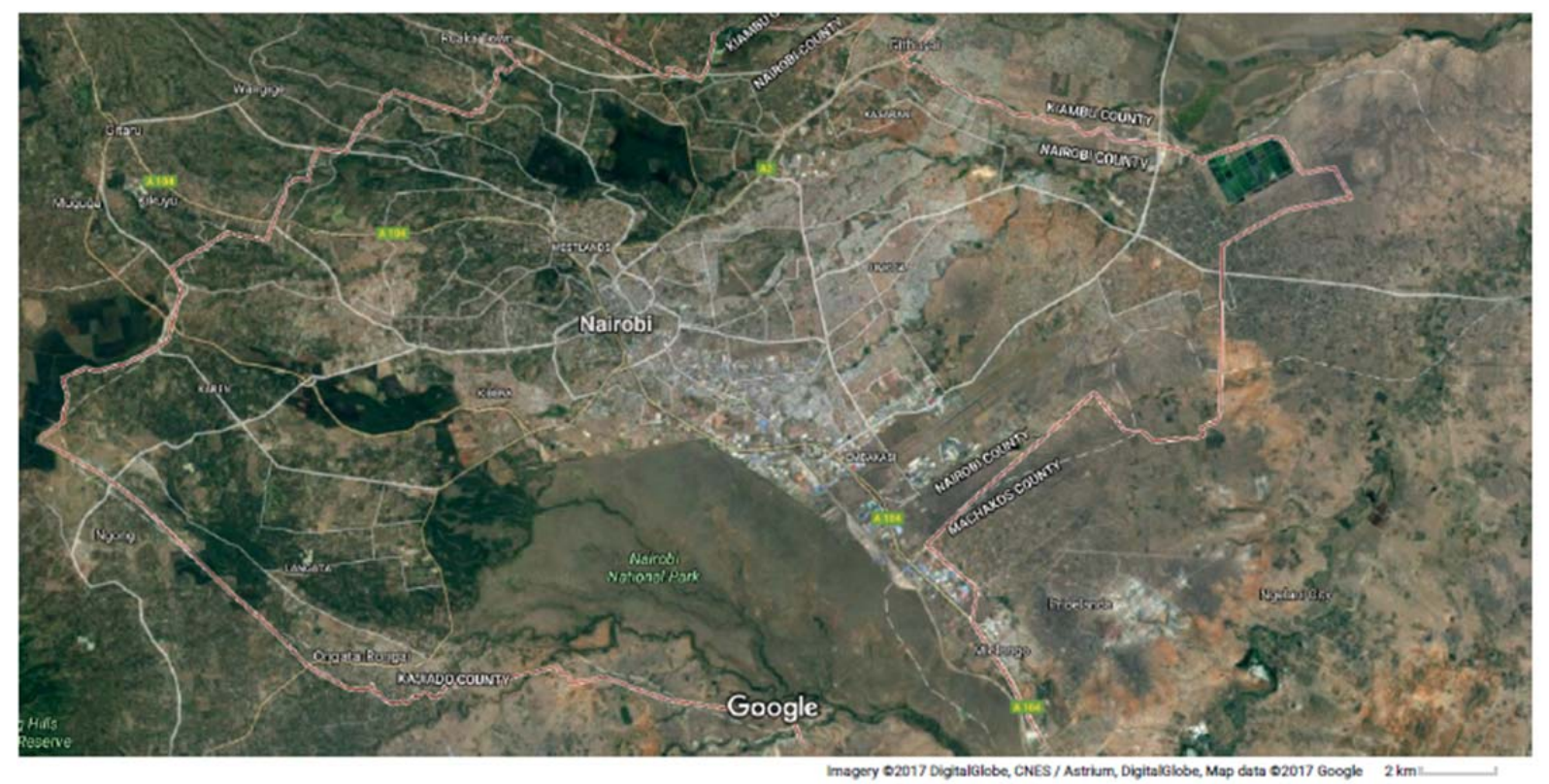

Figure I. Aerial map of Nairobi (from Google).

The deterioration of public and green open spaces' is not limited to Nairobi - statistics have revealed the loss of urban green spaces around the world. African cities are however leading in terms of the rate of deterioration of green spaces. The causes range from the fast urbanization rate, insufficient or outdated regulations, bureaucracy, corruption, lack of skills, financial constraints, to poverty and lack of awareness about the benefits of quality public spaces (Mensah, 20I4). As a result of these challenges, maintenance and upgrading of urban public spaces is not a priority for African governments and the spaces continue to degrade under the pressure of the increasing number of urban dwellers.

Research has shown the importance of quality public spaces for quality of urban life, given their environmental, social, and economic benefits. It is even believed that public space has the "potential to become a key generator of socio-economic growth" (UCLG, 2015). As such, there is a need to raise awareness about these benefits among African governments and the general public to make the upgrading and maintenance of public

\footnotetext{
' We refer predominantly to public open spaces that may be both green and grey spaces in this article.
} 
spaces in African cities a priority. Larger recreational parks and small-scale public open spaces both have an impact on quality of life of their users. This article will analyse and take a deeper look specifically at small scale open spaces in Nairobi, including courtyards, footpaths and streets across the city that urban dwellers use daily and have a more direct impact on daily life.

Noting the urgency to upgrade and improve public spaces across Nairobi, and the limited resources the Nairobi City County Government has to invest in these projects, Public Space Network (PSN) has focused on mobilizing communities, who are the users of these spaces, to take responsibility and accountability to transform, maintain, and preserve these spaces and to elicit quicker action, results, and a sense of ownership among the population.

\section{Nascent Efforts by Community Groups to Improve Their Neighbourhoods} In African cities, "urban social movements are emerging" (Cain \& Midi, 2017) to claim their right to the city and access essential urban services and liveable environments. As David Harvey argues, the right to the city is "a common rather than an individual right since this transformation inevitably depends on the exercise of a collective power to reshape the process of urbanization" (Carson, 2018). Community members coming together to reshape public spaces for community use is the key movement to claim the right to the city (Carson, 2018). Over the last decade, we have observed nascent efforts by community groups to improve their neighbourhoods in response to the lack of governmental capacity and limited resources to upgrade and maintain public spaces in Nairobi.

In many cases the groups, whose members are often unemployed youths, focus on correcting the non-existent or insufficient waste management systems. Usually they ensure a regular waste collection from residents, which offer an income generation while maintaining a space clean. Furthermore, some groups have started to organize regular clean-ups to remove waste dumped in these spaces or install creative dustbins on the streets to prevent littering.

Other groups have been beautifying their neighbourhoods through art. Graffiti and street art are the most commons ways to bring colour to the neighbourhoods, while conveying messages about social issues, empowerment, and education. The Hoperaisers Youth Group, from the informal neighbourhood of Korogocho, exemplifies this as they have run a successful project "Talking Walls" which the entire community participated in to beautify the streets.

Other communities have reclaimed their public spaces through sports. In the Mathare informal settlement, Mathare Environmental Conservation Youth Group (MECYG) transformed a neglected open space into a soccer field and began organizing soccer tournaments to engage and unite children and communities around sports. Similar activities are being undertaken by the youth group Reformers in the low-income neighbourhood Kayole, as well as in Korogocho by the Hoperaisers, who teach children roller-skating and organize skating competitions on the closed streets.

Similar to sports events, some other community-based organizations and youth groups are bringing communities together and reclaiming their public spaces through events, 
shows, and entertainment. This is exemplified by the Umoja Talanta group, which reclaims public spaces to strengthen social cohesion through dance and music.

The Dandora Transformation League (DTL), from the low-income neighbourhood of Dandora where petty theft and crime has been high under the context of high youth unemployment, has been mobilizing youths to take responsibility to transform previously neglected open spaces into clean, green, and safe community places through placemaking methods, often using low cost, locally available materials.

Unfortunately, while we could map these diverse and inspiring citizen-driven initiatives to reclaim abandoned and abused public spaces across Nairobi, they still remained isolated and localized with one group often unaware of the existence of another group nearby. The potential for a large-scale impact has thus been hindered by the lack of framework to connect the initiatives with each other and the lack of collaboration amongst groups, communities, and stakeholders.

\section{Building the Placemaking Movement Through a Gamification Approach}

Innovation thrives and grows in environments that encourage collaboration (Paulus \& Nijstad, 2003). PSN remains convinced that each initiative could have a stronger impact and elicit greater change if the groups can see what they are each doing and share ideas. Many of the activities are complementary and groups can enrich their activities by learning from one another's successes and failures.

In addition to creating an environment for collaboration and showcasing existing efforts, PSN sought to create an environment that would incentivize community groups to take care, ownership, and accountability for their public spaces, and to eventually create a movement of citizens shaping their public spaces according to their needs.

Therefore, we applied a gamification approach to bring the existing and aspiring placemaking groups across Nairobi together around the common cause of public space upgrading via the Changing Faces Competition (CFC). The CFC drives and empowers youths to change the face of their neighbourhoods and transform their mindset to one of responsible, accountable community members who take ownership for the cities, streets, and spaces in which they live.

Any group that is formally registered with the government (self-help groups, community-based organizations, residents associations, etc.) can register for CFC and identify a neglected public open space in their neighbourhood they wish to transform into a clean, useable community space. They crowdsource the resources for the transformation to create a new, public, shareable space - such as a playground or park using locally available and donated materials and equipment and creative placemaking methods. The best teams are selected by the jury of urban experts and announced at an awards ceremony, where winning teams receive a monetary award.

The competition was successfully piloted by the Dandora Transformation League (DTL), a founding member organization of our network, in Dandora neighbourhood for 3 competitions since 20I4. DTL has managed to mobilize over 3,000 youths that transformed 120 public spaces in the neighbourhood. After the success of the concept in Dandora, people from other parts of Nairobi started to express interest in bringing the competition to their neighbourhoods. Public Space Network (PSN) leveraged our networks with diverse expertise and experience, and existing members operating in different parts of the city, to scale the competition in 2018 to the city scale. 
The recruitment strategy, relying predominantly on our community champions spreading the word in their communities, led to the participation of II 4 community groups from mostly lower-income neighbourhoods and informal settlements across Nairobi in the competition. These groups transformed public spaces, with over 60 sites being selected for visits by the jury and urban experts who selected 10 finalists who were honoured and received awards at the ceremony.

In this competition teams need to innovate and be creative to get among the top ten. While the common base element for most of the teams was a thorough clean-up of the site, additional elements for transformations were very diverse: from teams using art to bring colour in their neighbourhood, educating their community about maintenance of public spaces, and conveying messages about social issues. Others created sports fields and introduced programmes to engage street children around sport activities and used recycled waste material to create playground equipment and benches for community parks.

The winning team cleaned the polluted Nairobi River which runs through the Korogocho informal settlement, cleaned the dumpsite that was on the bank, and planted grass and trees to create a clean and green oasis for the community to enjoy. Given the diversity of interventions, the teams have been encouraged to visit each other's sites and continue to enrich each other, learn, and grow by sharing experiences.

Another key element of the interventions is sustainability. The teams are invited to explore the productive function of the space and to identify income-generating activities related to the maintenance or community use of the space to cover the maintenance costs in the long-term. In residential areas, tenants and landlords of plots surrounding the space tend to agree to contribute to regular monthly contributions for maintenance, security and waste collection ensured by the youth group. Some groups created multifunctional sites that can serve as playgrounds during the day and a commercial parking at night. With a new clean, artistic and/or green face, other sites now attract musicians to shoot their video clips, couples to take their wedding photoshoots, organizers of art or community events to host their functions. All these activities have the potential to provide income to the group in charge of the maintenance of the space, ensuring that they keep transforming the space after the competition. This excludes additional benefits such as safer communities, better property values, and other social and economic benefits.

Beyond the "fun" aspect of a competition and the transformation of a large number of spaces at a low cost, there is another important benefit: raising awareness. It raises awareness among the users of the spaces about the value and benefits of quality and clean public spaces, individual accountability and responsibility in managing the spaces, and maintaining the spaces for the future. For many living in lower-income neighbourhoods, the deteriorated spaces had become the norm and communities were unaware or ignored how they could easily have an active role in changing this status quo. Our community champions and recruiting teams helped show aspiring change makers the way to improve their neighbourhoods and spaces, and how communities using the selected spaces could experience and appreciate having access to a quality clean and green community space where they can safely interact with their neighbours, exercise, rest, or let their children play. The competition educates the general public 
about how and why to keep their spaces clean, and that they should have access to quality and safe public spaces in their area.

Secondly, the competition results in engaging public authorities and raising their awareness about the importance of public spaces. The community champions first have to seek a moral endorsement of local authorities for the grassroot interventions. Subsequently, the authorities tend to start feeling a bottom-up pressure to support the interventions more actively as the community takes over the part of the government's mandate, demands support and unites around the initiatives.

\section{Building Partnerships for Sustainability}

PSN first focused on building a grassroots movement to reclaim public spaces, with citizens taking ownership of public spaces being the drivers of sustainability. However, citizens alone would have a hard time growing and maintaining the movement and impact if they were alone in their efforts. Building alliances with partners, from the public and private sector that support the grassroots movement with expertise, materials, equipment, financial and technical resources is key to scaling the potential impact and ensuring long-term sustainability.

The competition also serves as a platform to connect the community groups with key stakeholders. During the first Nairobi-wide competition, interested experts (architects, urban planners, urban designers) volunteered their time to advise teams on inclusive designs using the available materials. Private businesses donated materials for transformations as part of their Corporate Social Responsibility (CSR) efforts and local public authorities started to support the initiatives by facilitating the approval process and providing material and tools.

The competition facilitates collaboration and synergy, bringing together stakeholders and partners and raising awareness and increasing visibility of participating partners. This increases the sustainability of the initiatives far beyond the competition and its framework, allowing it to empower and impact other areas and unite communities around placemaking movements.

Our approach refers to Ostrom $(1998,2005)$ theories of self-organized systems for robust common-property institutions and polycentric systems. While a communitydriven management of urban commons that public space represents enhances sustainability due to the creation of a sense of ownership by the community, the cooperation with other like-minded organizations, public authorities, private sector and academia can maximize the impact of locally based initiatives through knowledge and resource sharing.

\section{Conclusion}

Building a citizen-led movement to reclaim public spaces in fast-growing, resourcelimited cities like Nairobi is needed to ensure all urban dwellers have access to quality public spaces near their homes. Public authorities facing numerous challenges, such as issues related to fast urbanization, limited financial resources, lack of knowledge, bureaucracy, and outdated regulation or corruption do not have the capacity to ensure a sustainable management of small-scale public spaces across the city. However, these are the spaces used most often by urban residents on a daily basis for a wide range of 
activities. The users of the spaces are the best drivers of the transformation movement, knowing the challenges, importance of quality spaces, and impact on their daily lives. The of the biggest obstacles we identified to building such a movement is the lack of awareness about the benefits of quality of public spaces and the role citizens can play in their management. Applying a gamification approach to public space upgrading raises awareness among the general public, mobilizes a large number of community groups to join the placemaking movement, and advocates for placing public space upgrading among urban priorities.

However, to ensure the highest large-scale and long-term impact, the grassroots movement cannot remain isolated and needs to build partnerships with public and private sector stakeholders to leverage their resources. From our experience in Nairobi, other stakeholders express interest in joining the movement once they see the results of these community-driven interventions. Our goal is that the competition acts as a catalyst for creating a framework for the cooperation of diverse stakeholders to challenge the fragmented urban pattern of cities like Nairobi, and to co-create inclusive equitable cities through multifunctional vibrant public spaces distributed throughout and improving the quality of life of each citizen.

\section{References}

Cain, A. \& Midi, A., "African Struggles for the Right to the City", Global Platform for the Right to the City [online]. http://www.righttothecityplatform.org.br/african-struggles-for-the-right-tothe-city. Accessed on 17 September 2019.

Carson, J. (2018). "Citizen Spaces, Experiments in Reclaiming the Right to the City", Emily Carr University of Art + Design, available at: https://designawards.core77.com/BuiltEnvironment/83070/Citizen-Spaces-Experiments-in-Reclaiming-the-Right-to-the-City.

Mensah, C. A. (2014). "Urban Green Spaces in Africa: Nature and Challenges”, International Journal of Ecosystem, Vol. 4, No. I, PP I-II.

Ostrom, E.(1998). 'A Behavioral Approach to the Rational Choice Theory of Collective Action', The American Political Science Review, Vol. 92, No. I, pp. I-22.

Ostrom, E. (2005). 'Robust Governance in Polycentric Institutions', in Ostrom, E., Understanding Institutional Diversity, Princeton University Press, Princeton.

Paulus, Paul B. \& Nijstad, Bernard A. (2003). Group Creativity: Innovation Through Collaboration, Oxford University Press.

UCLG (20I5), "Challenges and opportunities of public space as a generator of growth in African Cities" [online]. https://www.uclg.org/en/media/news/challenges-and-opportunities-publicspace-generator-growth-african-cities. Accessed on 17 September 2019. 


\section{Public Space Network}

Public Space Network (PSN) is a Nairobi-based non-profit association that brings together a diversity of stakeholders involved in public space management in Nairobi, driven by the vision to improve the quality of life for all Nairobians and make Nairobi a world-class city, by creating clean, safe, healthy, inclusive, vibrant and connected public spaces. PSN provides an enabling environment for community-driven public space regeneration projects to reach scale. The network connects the community groups with the key actors and ensures a sustainable citywide public space management through a Public-Private-People Partnership model. The flagship project of the organization is the international award-winning mobilization tool Changing Faces Competition.

https://www.publicspacenetwork.org/ 


\section{Changing Faces Competition}

Changing Faces Competition (CFC) is the PSN flagship project. It is a fun mobilization tool to engage community groups to take responsibility for transforming and maintaining public open spaces in their area. CFC is a platform that empowers citizens to become the lead actors in public space management and creates a grassroot movement of citizens transforming their public spaces. It is also a platform to raise awareness and advocate for policy placing a sustainable public space management among urban priorities. The competition was piloted for three editions at the neighbourhood scale in Dandora lowincome neighbourhood and was scaled to Nairobi city scale in 2018. Over 200 community groups got involved since its inception, transforming the same number of spaces. The concept received two international awards for its potential to engage many citizens and transform a large number of spaces at a low-cost: Dubai International Award for Best Practices to Improve the Living Environment and Le Monde Smart Cities Award in category Global Citizen Engagement.

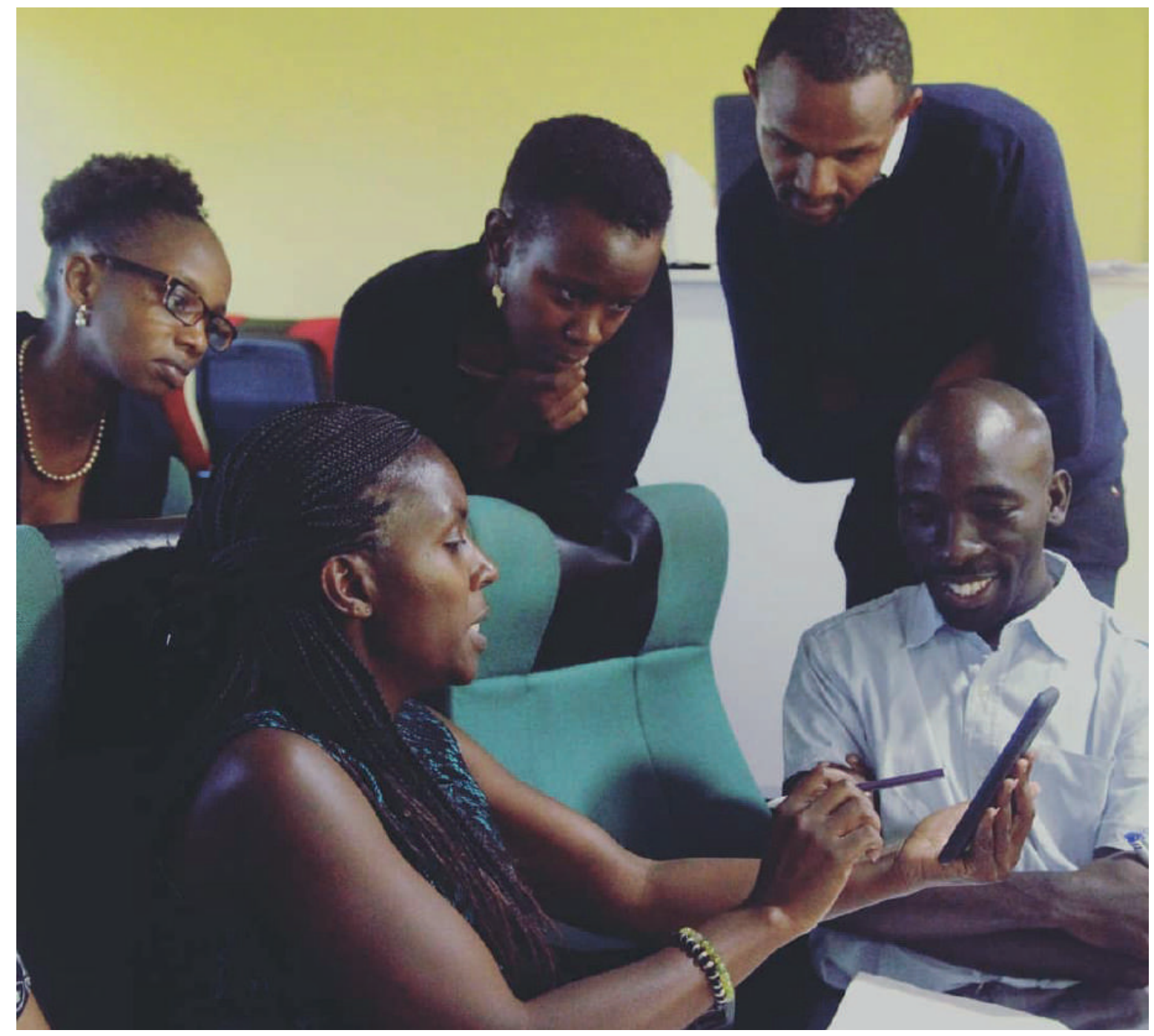

69 | The Journal of Public Space, 4(3), 2019 | ISSN 2206-9658 City Space Architecture / UN-Habitat 


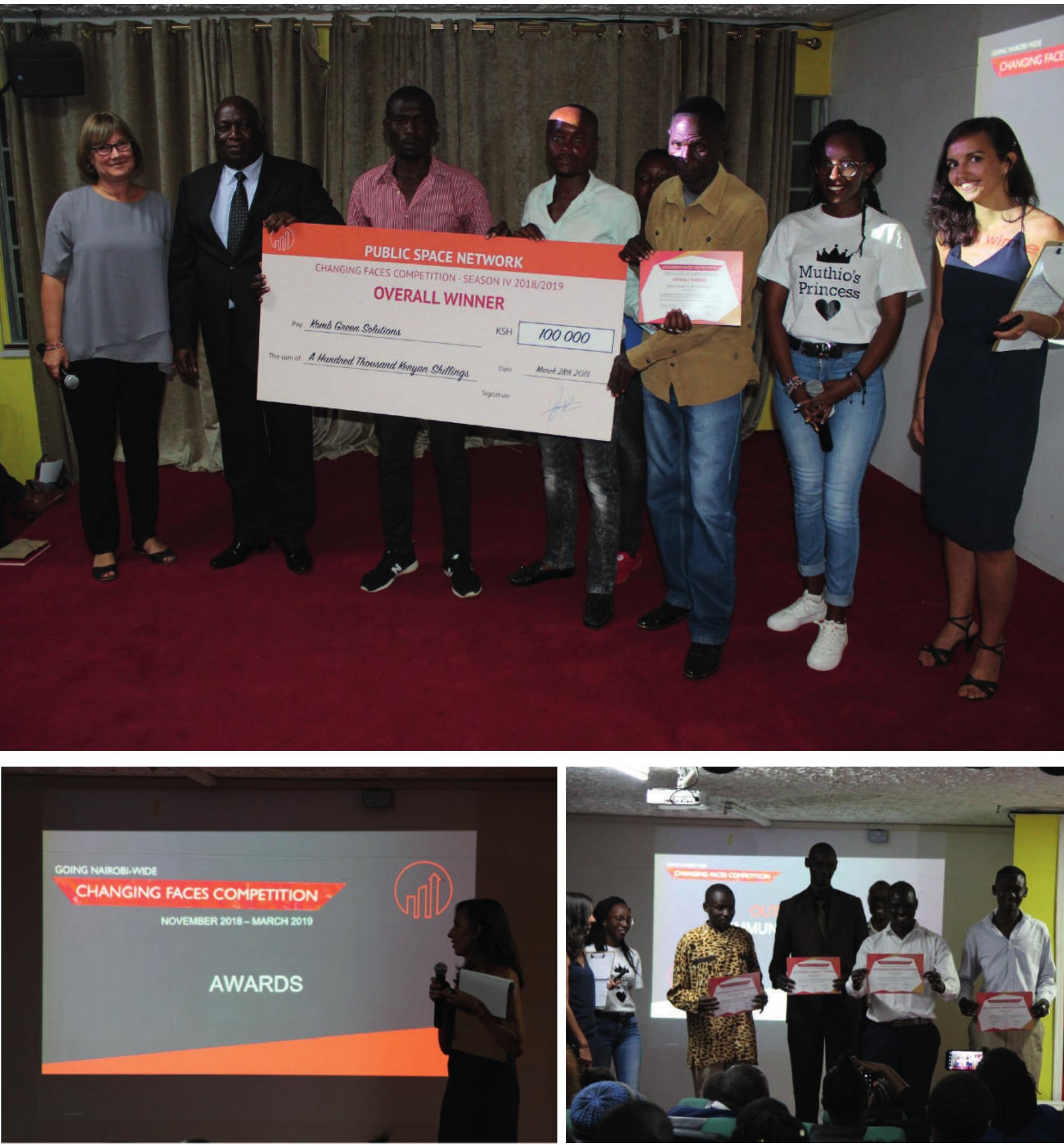

70 | The Journal of Public Space, 4(3), 2019 | ISSN 2206-9658

City Space Architecture / UN-Habitat 
Under the Changing Faces Competition, the community groups design and implement their own projects. Public Space Network is the facilitator mobilizing the groups, connecting them with other stakeholders such as public authorities, private sponsors and urban experts, and developing their skills to transform a space. PSN recruits community champions who are community leaders and know their communities and local authorities. The community champions are trained in placemaking and community engagement skills and are in charge of recruiting teams, guiding them in regard to their site transformation and engaging local authorities to receive their endorsement and support. During the Nairobi edition 2018/19, 10 out of I 4 participating teams were nominated for awards by a panel of judges. Below are details about some of the most outstanding projects.

\section{Komb Green}

The winning team of the first Nairobi-wide edition of the Changing Faces Competition in 2018/19 comes from the informal settlement of Korogocho. Komb Green focused on one of the biggest and most challenging public space issues in Nairobi: the polluted Nairobi River and its banks.

Komb Green is a youth group composed of 70 members, equally balanced between men and women. In the context of high youth unemployment, many of the members used to be involved in petty crime - thefts, mugging or sex work. Many of their close friends lost life in clashes with police and some started to realize they need to reform themselves and start doing some meaningful activities for a better life.

In 2017, they decided to start restoring a section of the riverbank by the Nairobi

River passing through their informal settlement that used to serve as a dumpsite. They removed the garbage covering the land, planted grass and trees. To prevent flooding, they strengthened the bank by building walls from stones collected in the river to separate the bank from the river. To make the space more pedestrian friendly, they created a paved footpath through the park connecting to the stairs that they also built, that lead to the
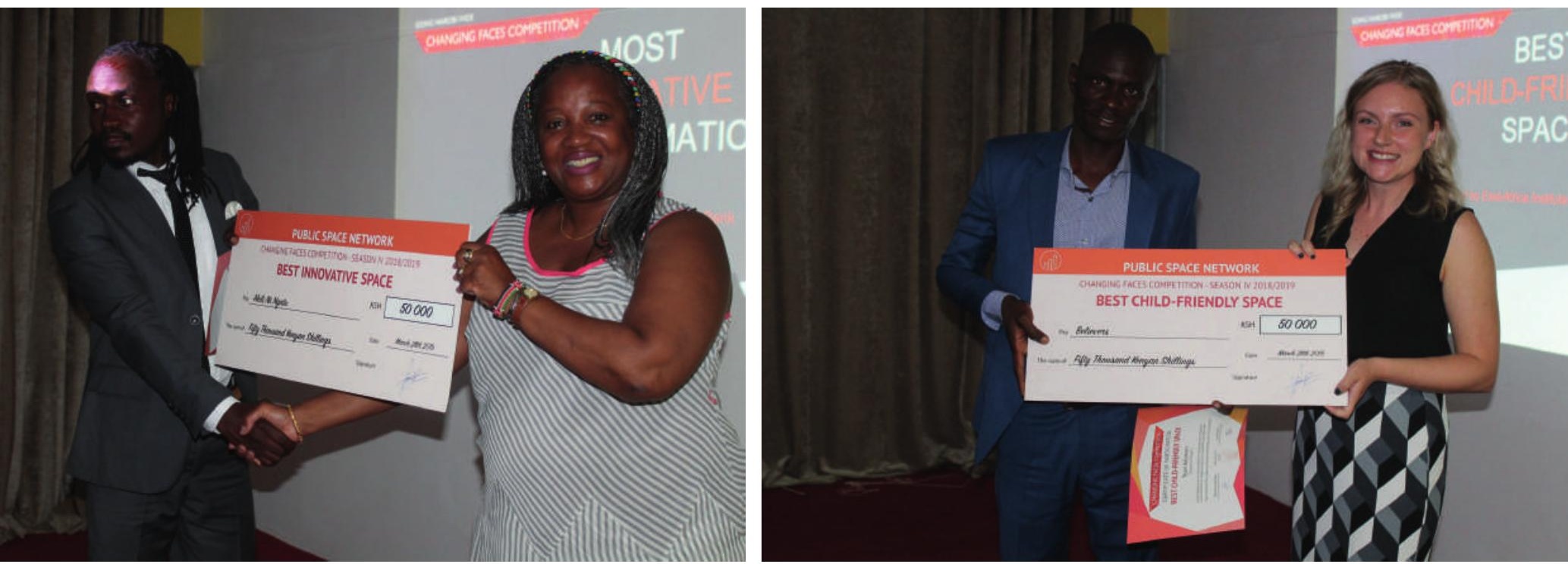

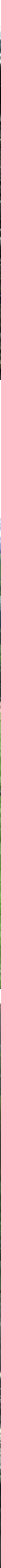

72 | The Journal of Public Space, 4(3), 2019 | ISSN 2206-9658

City Space Architecture / UN-Habitat 
adjacent bridge. The park is the only green and clean space in the neighbourhood that the community can freely enjoy.

Further to the green park, the group cleaned the adjacent space with a vision to transform it into a playground for children. Through a partnership with a foreign foundation, they received playground equipment that bring attention of hundreds of children from the whole area.

More importantly, the group has adopted a long-term agenda to clean the river.They started by removing the solid waste from their section of the river and stones making the solid waste to pile up. After bringing attention of stakeholders from other parts of Nairobi to their intervention, they started to participate in stakeholders' forum to establish a more holistic strategy to clean urban rivers and share their experience with other community groups operating around the Nairobi River.

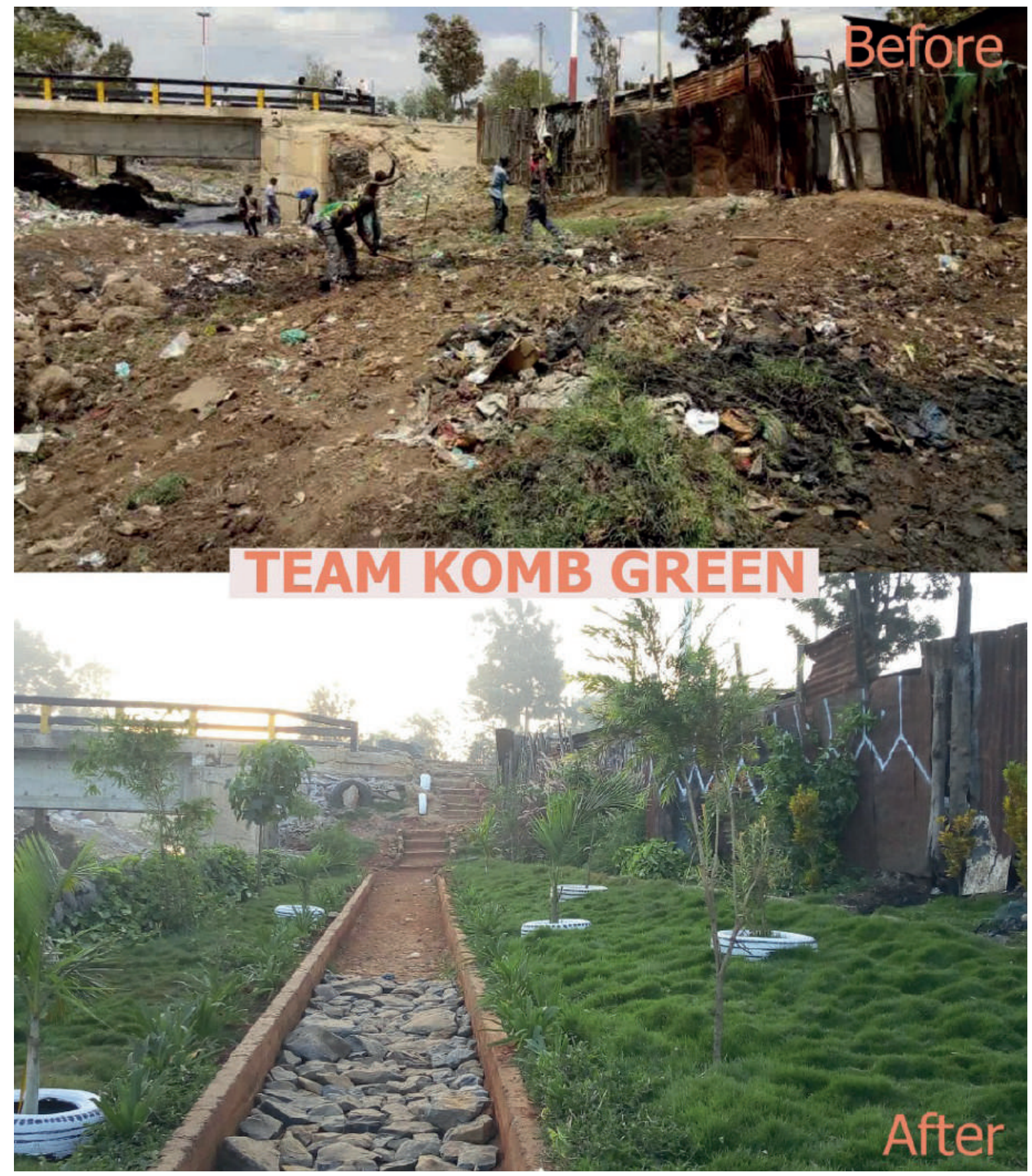

73 | The Journal of Public Space, 4(3), 2019 | ISSN 2206-9658 City Space Architecture / UN-Habitat 
A

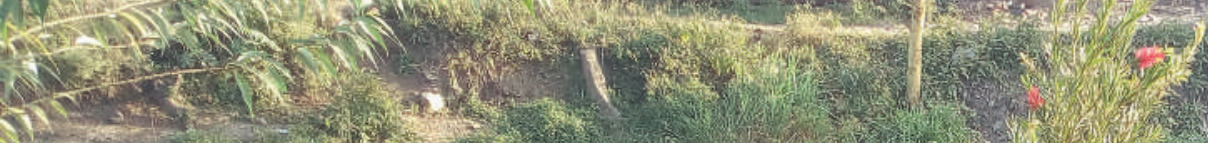

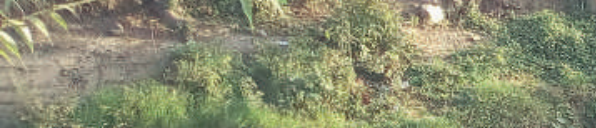

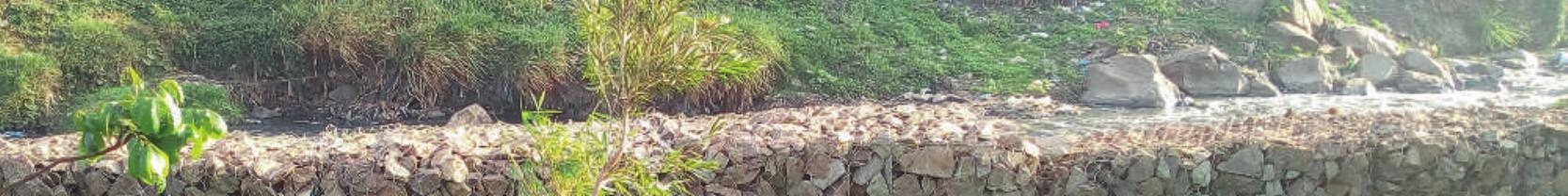

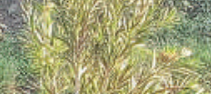

Sill

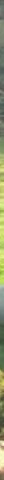

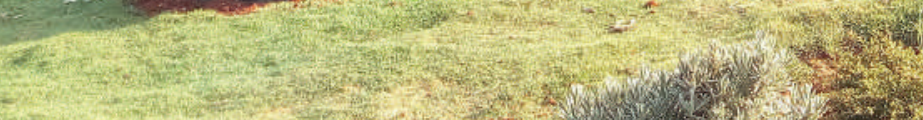

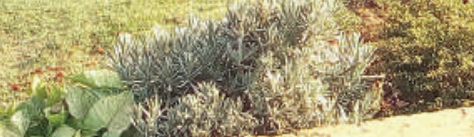

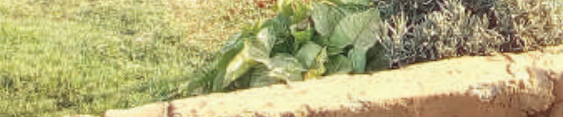

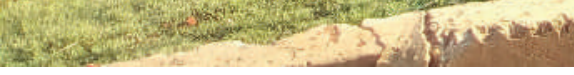

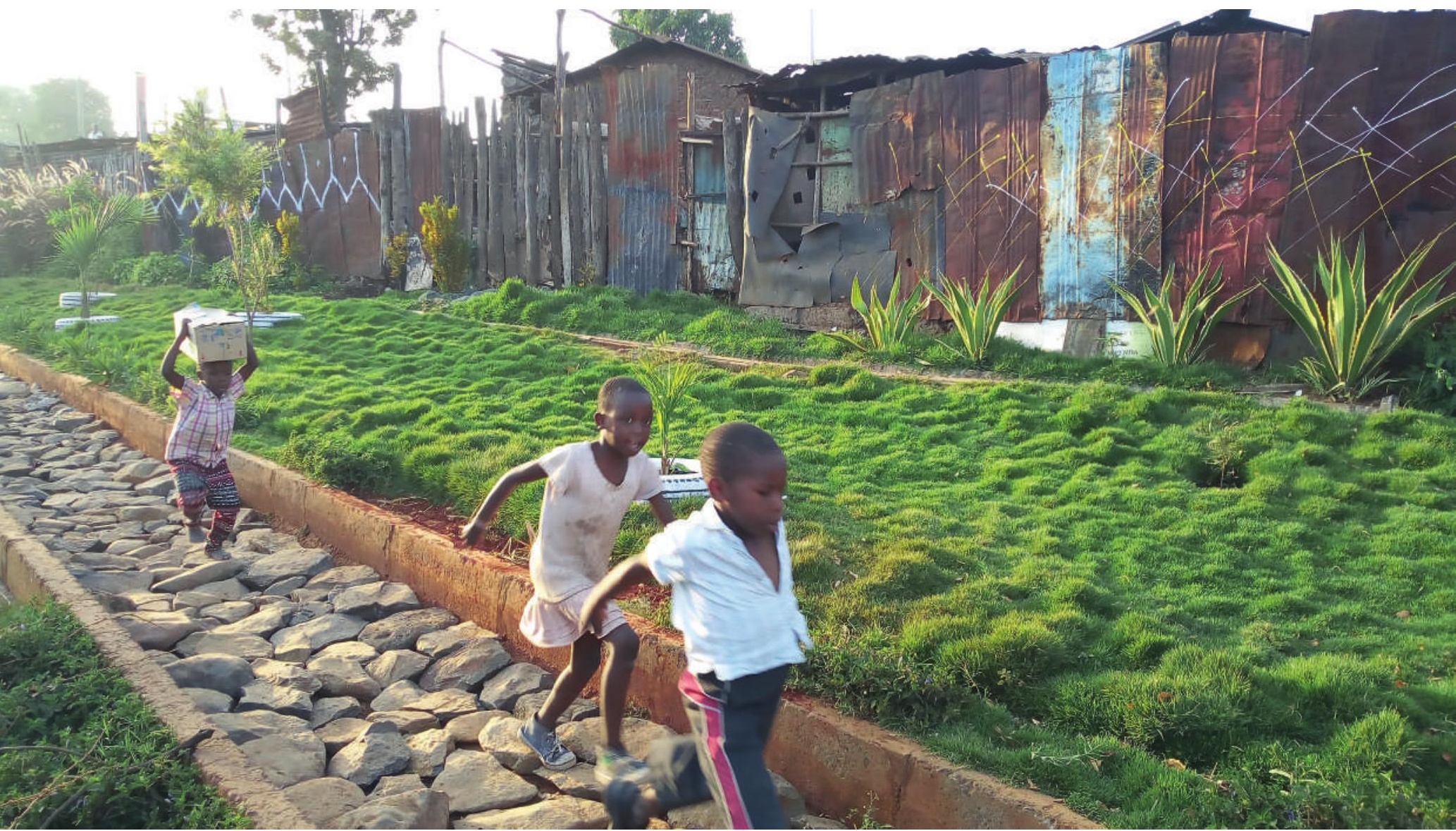

74 | The Journal of Public Space, 4(3), 2019 | ISSN 2206-9658

City Space Architecture / UN-Habitat 


\section{Believers}

Believers received the Best Child-friendly Space Award in the Nairobi-wide Changing Faces Competition 2018/19 and are one of the youth groups operating under the umbrella of Dandora Transformation League, PSN founding member organization, in the low-income neighbourhood of Dandora. The group is composed of I 3 active members. Their space is referred to as a courtyard and is surrounded by residential plots. Residents used to dump waste on the open space and part of the space was covered by overgrown bushes.

The open space is fragmented by the plots into several sections, each having a different function. All sections are connected by a footpath that has been levelled and clean-up, with the adjacent drainage being reopened for the water to flow away.

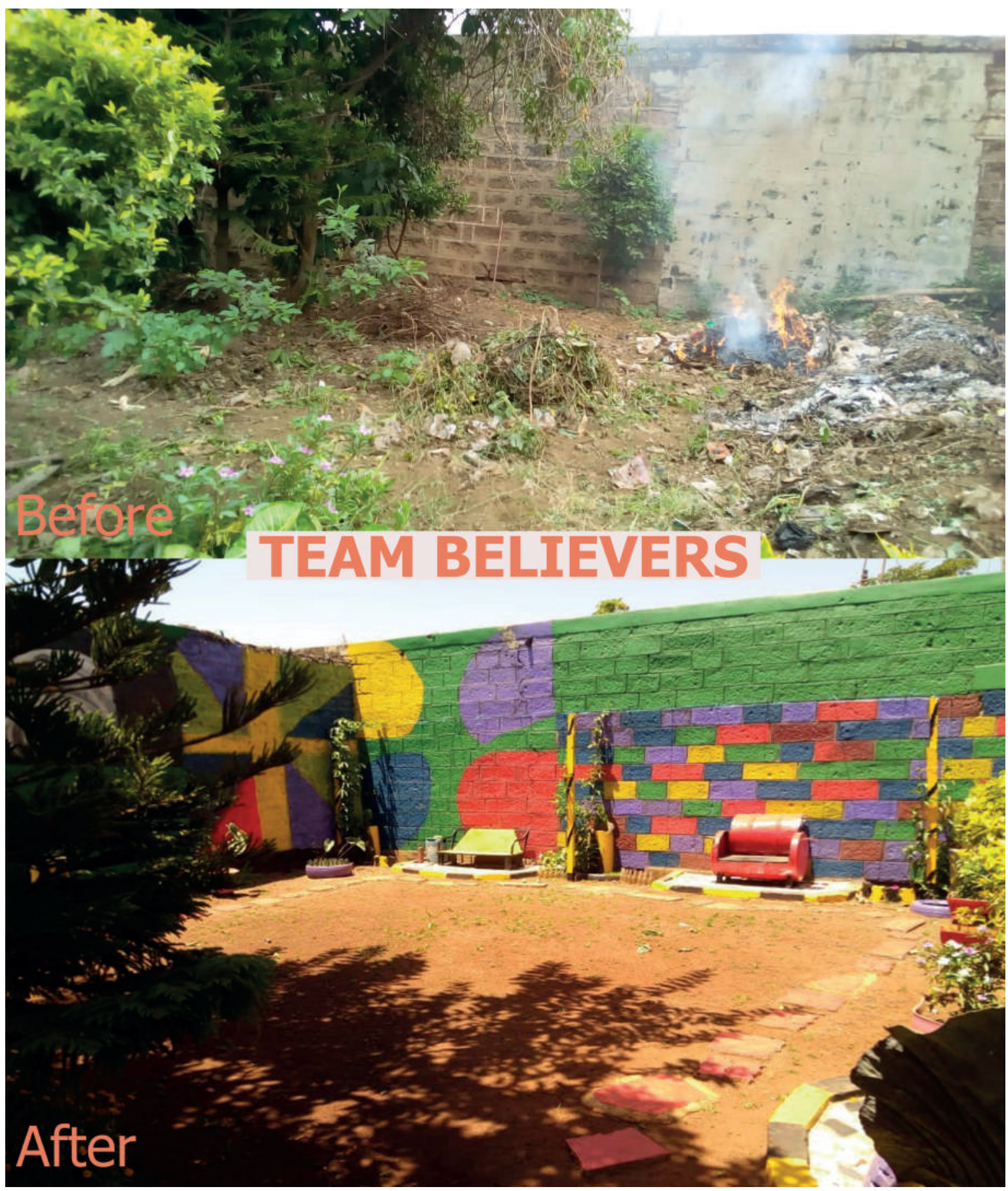

75 | The Journal of Public Space, 4(3), 2019 | ISSN 2206-9658 City Space Architecture / UN-Habitat 

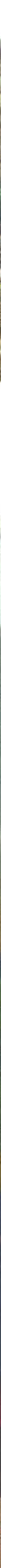

76 | The Journal of Public Space, 4(3), 2019 | ISSN 2206-9658

City Space Architecture / UN-Habitat 
One section serves as a park to rest. A tall fruit tree provides shade and well-maintained grass and planted flowers add more greenery to the space. The group has leverage on reusing of the waste material, such as old tyres, iron drums, pieces of drainage, but also old gum boots, toilets or old computers, to build seats, benches and flowerpots.

To bring more colour to the space, the group painted the walls surrounding the space. Believers thought about every little detail to make the park a real paradise for the community: small notes with inspirational quotes hang on trees and flower pots across the garden and animals have made the garden their home too: an aquarium with fish is situated in the shade under the tree, a tortoise sleeps in the corner, a cat lies on the sun. A small structure in the corner of the garden is an upcoming library.

Another section of the Believers courtyard offers playground equipment such as a seesaw and a swing, built locally by the group. Las section was levelled to provide a flat surface. During the day, children play ball games on the site and at night it serves as a commercial parking.

After initiating the transformation of the site as volunteers, the residents living around the site agreed to contribute KES I00 (USD I) per month per household in exchange for a regular clean-up of the space, security and waste collection.

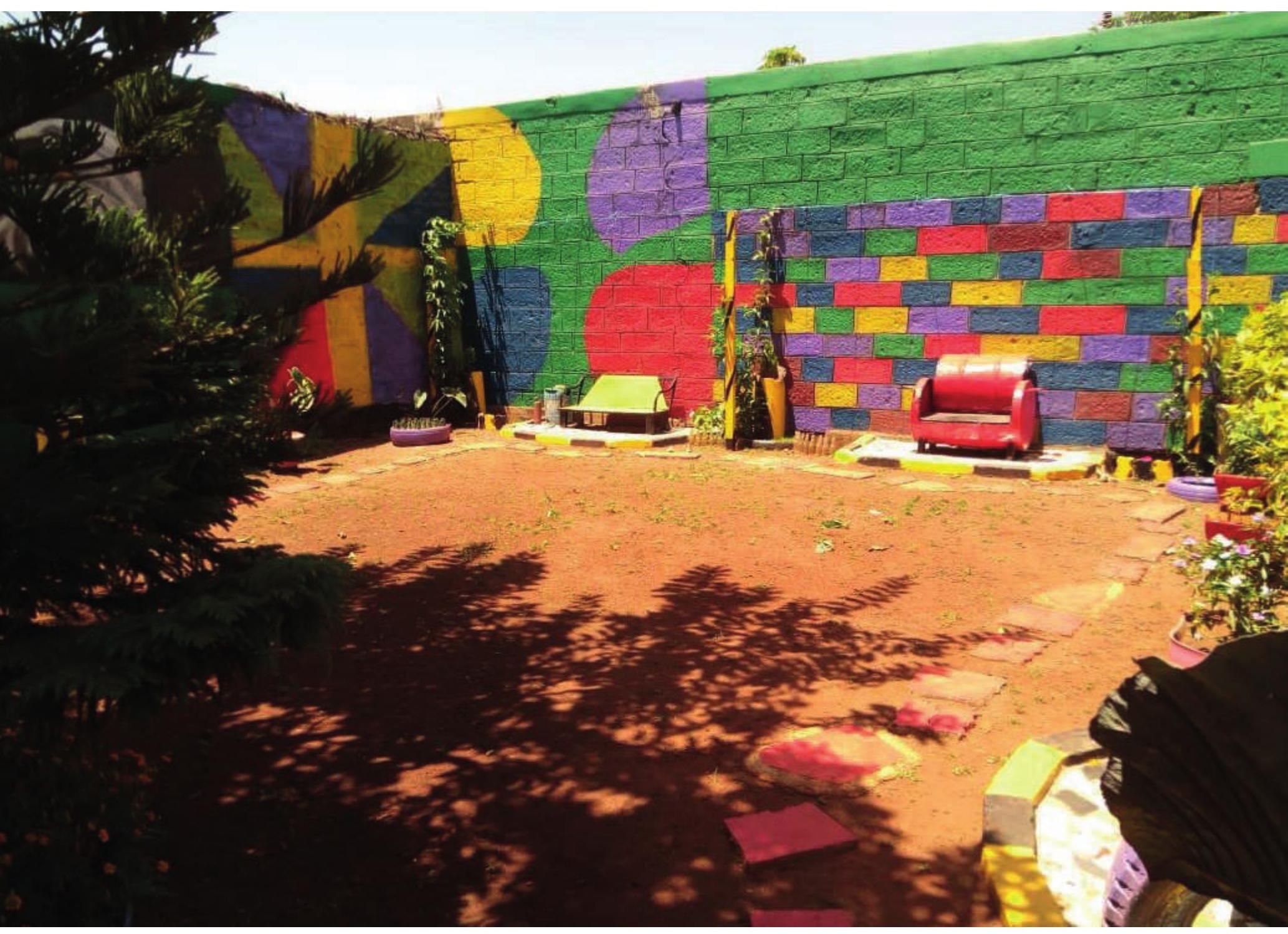

77 | The Journal of Public Space, 4(3), 2019 | ISSN 2206-9658 City Space Architecture / UN-Habitat 


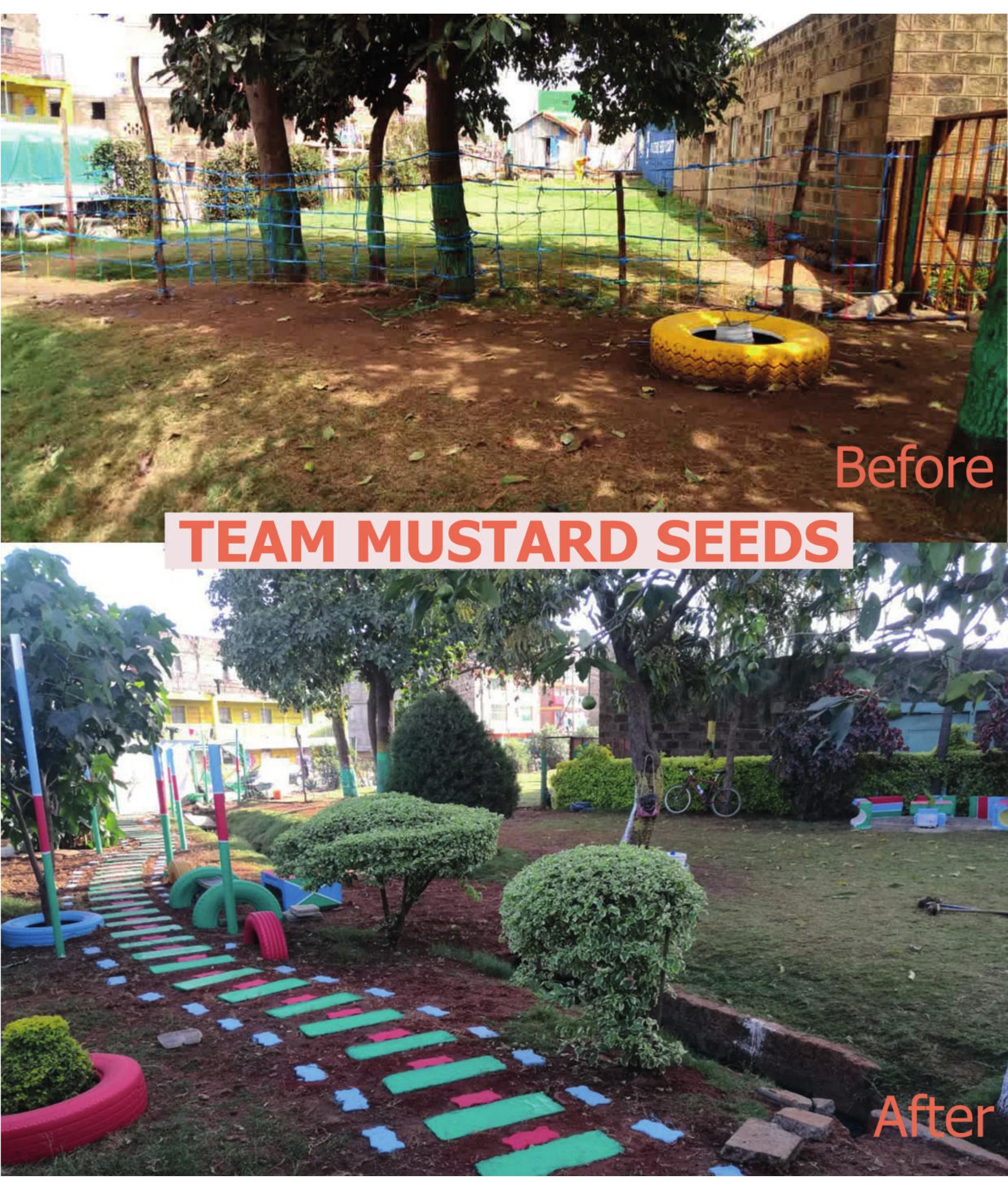

78 | The Journal of Public Space, 4(3), 2019 | ISSN 2206-9658

City Space Architecture / UN-Habitat 


\section{Mustard Seed}

Mustard Seed is the first pilot space that was transformed in Dandora by the founder and CEO of the Dandora Transformation League, Charles Gachanga. In 20 I4, Charles did not want to passively observe his dirty neighbourhood and children playing with the waste dumped outdoors and decided to start transforming the first space. He organized a community meeting and invited the members to join him in the clean-up exercise. At first, only two his friends joined him and started the hard work of removing the garbage, levelling the ground and digging to open up the drainages that had disappeared over time under layers of debris.

Same as Believers courtyard, Mustard Seed also has more sections. One serves as a garden, another as a playground and are connected by a restored footpath. The playground offers swings and a slide created from locally available materials such as tyres and iron poles. The garden offers a lot of shade thanks to trees, flowers and shrubs. The group introduces benches made from tyres, wood planks and pieces of old unused drainage and recently opened a public toilet next to the space.
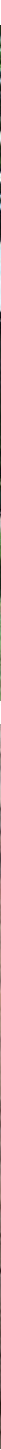

79 | The Journal of Public Space, 4(3), 2019 | ISSN 2206-9658 City Space Architecture / UN-Habitat 

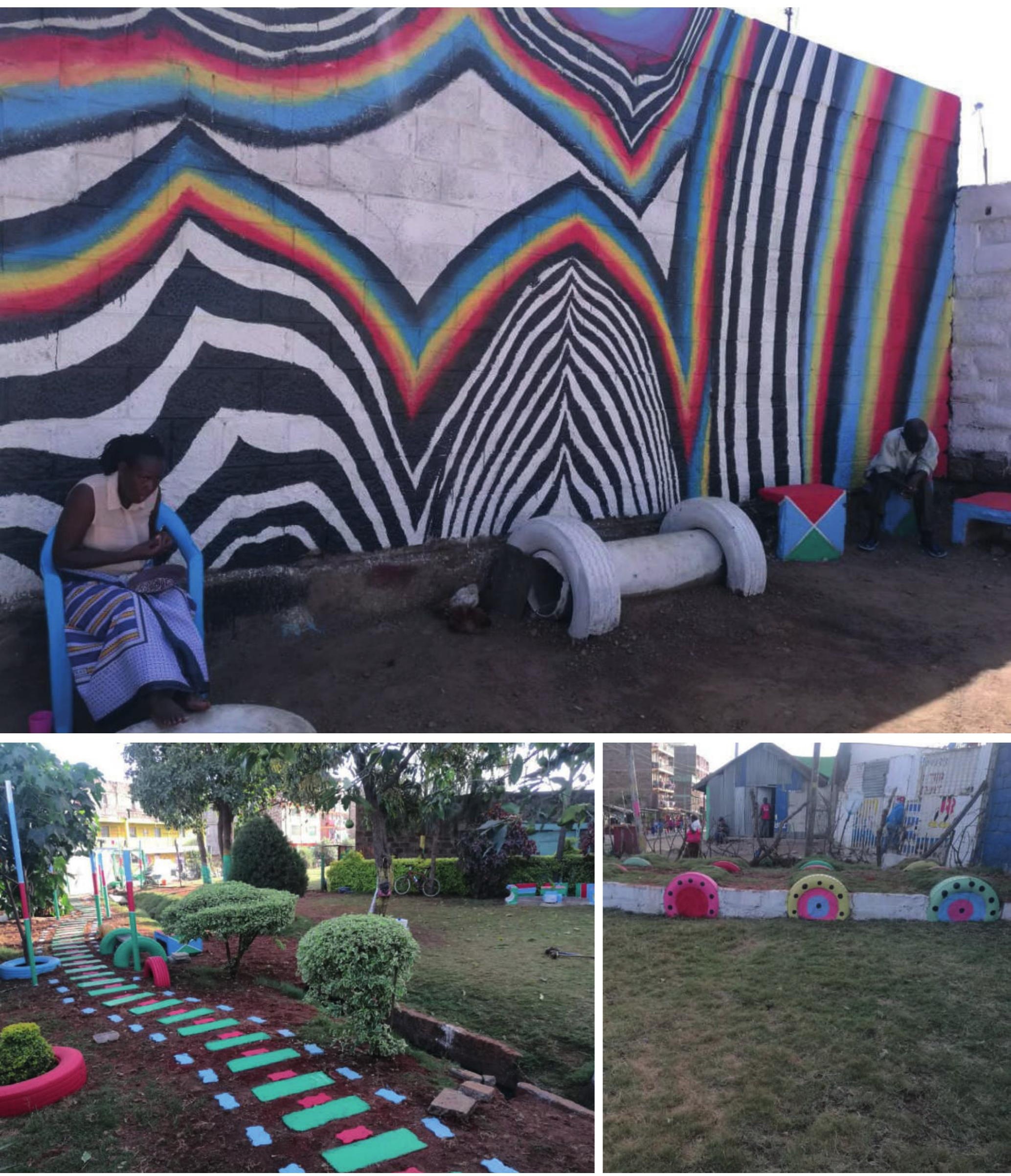

80 | The Journal of Public Space, 4(3), 2019 | ISSN 2206-9658

City Space Architecture / UN-Habitat 
Mustard Seed was at the beginnings of the Changing Faces Competition. After the great transformation, Changing Faces Competition was suggested as a fun mobilization tool to inspire more youth groups in Dandora to replicate the same type of intervention on other places in the area. Over the last five years, Mustard Seed has inspired over two hundred groups working on the same number of sites to replicate the community-driven model. Mustard Seed keeps changing and innovating. In addition to the regular maintenance, the group keeps adding new elements to the site: new painting, benches, stage for events etc.
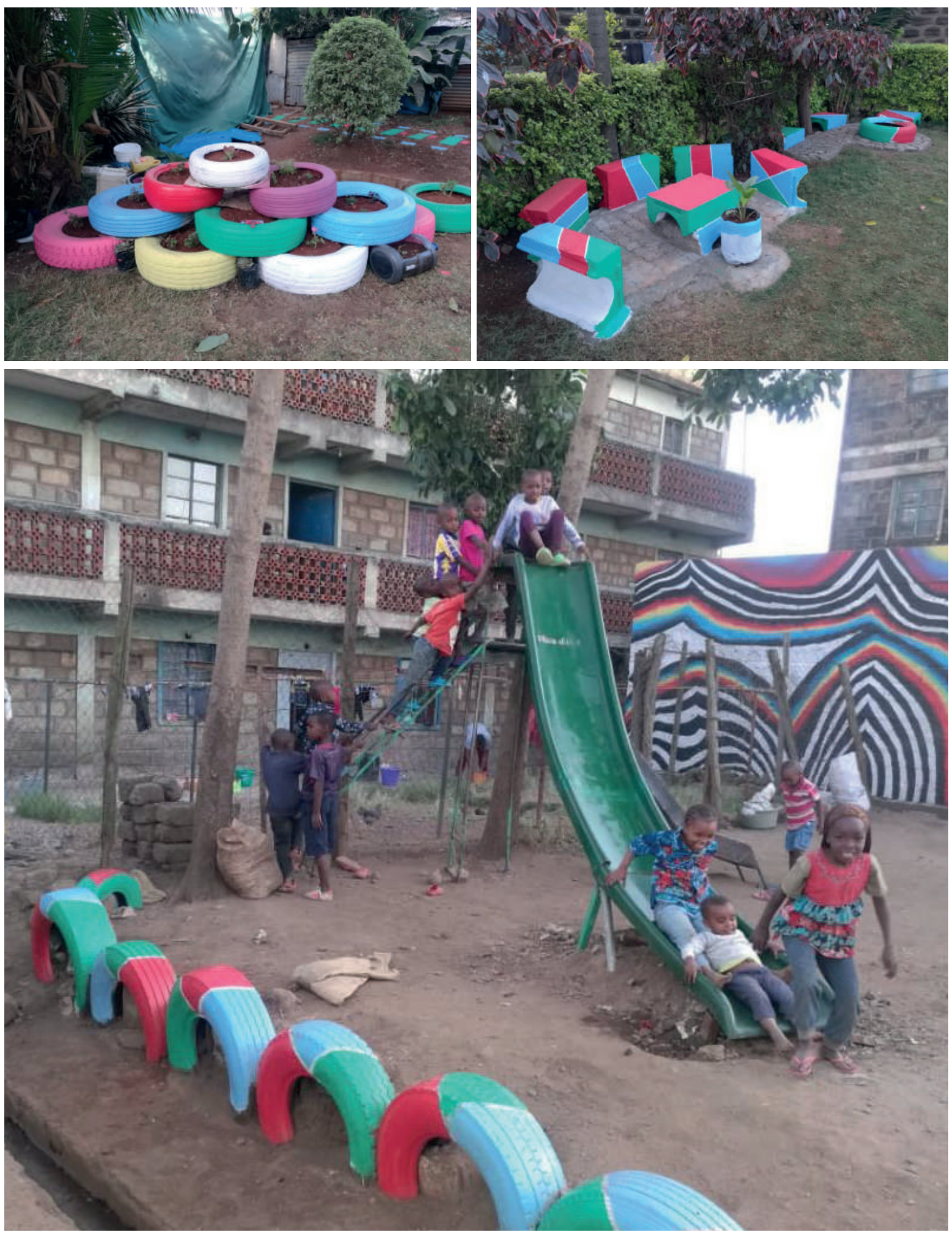

8I | The Journal of Public Space, 4(3), 2019 | ISSN 2206-9658 City Space Architecture / UN-Habitat 


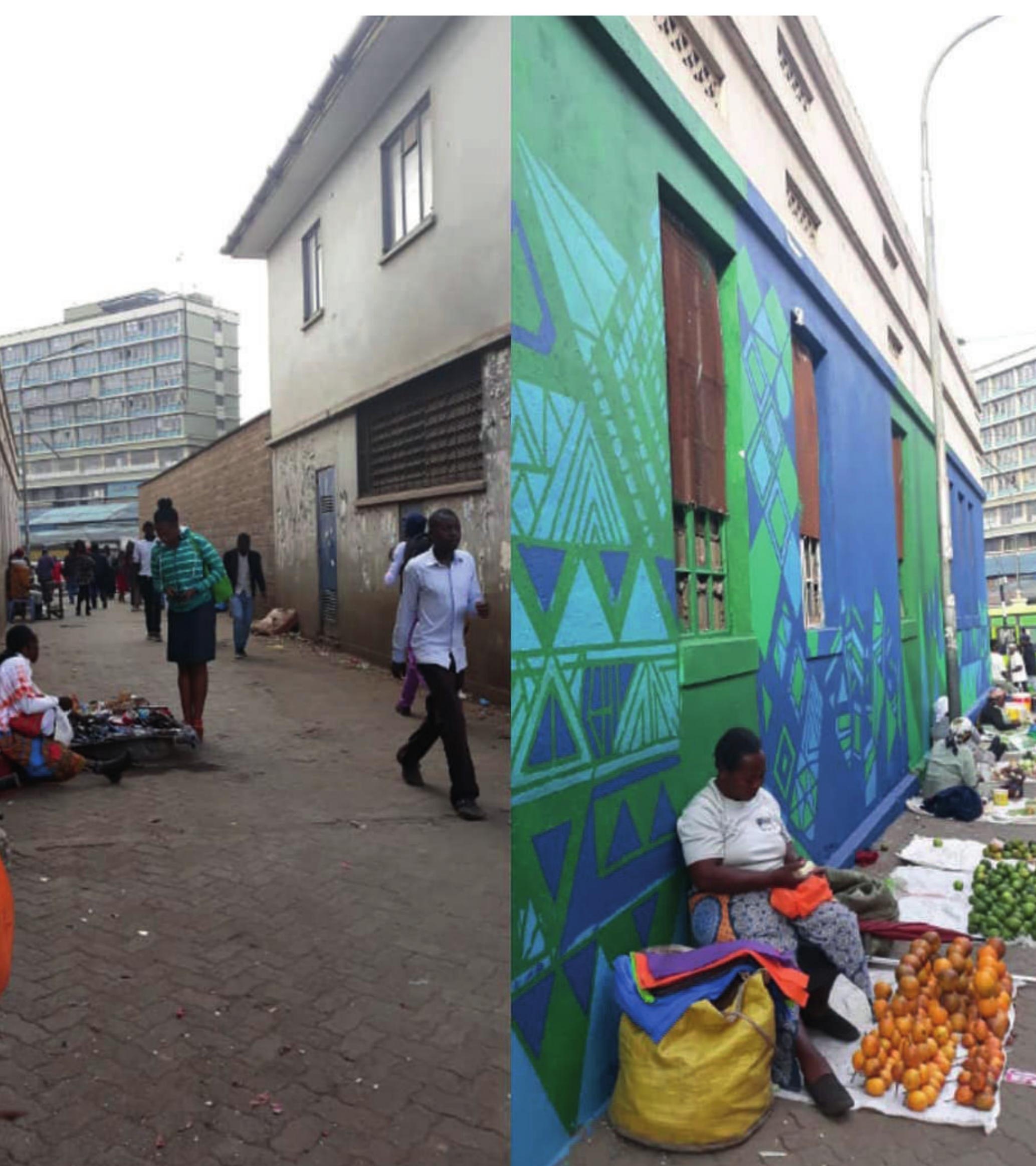

82 | The Journal of Public Space, 4(3), 2019 | ISSN 2206-9658 


\section{Turkana Lane Wall}

In addition to the Changing Faces Competition, Public Space Network has organized Placemaking Days, during which it brought together Nairobians from different parts of the city to volunteer to transform a selected site.

Turkana Lane is a vibrant pedestrian lane in Nairobi downtown, connecting a bustling Nairobi Bus Station with a busy road. It mostly serves as a transit space and street vendors sell fruits, vegetables and other items to passers-by.

The lane used to be a fairly clean but being enclosed between two buildings, it was very grey. The major goal of the project was thus to beautify the space by painting the wall on one side of the lane.

Public Space Network selected two paint colours that were suggested by the owner of the building that serves as a medical centre. The painting was supervised by one professional artist who gave simple guidelines to the participants who came from different backgrounds and neighbourhoods of Nairobi. Through the collective creativeness, the participants created a beautiful abstract pattern that has brought light to the lane. The street vendors operating on the lane welcomed the intervention as it has provided a more enjoyable working environment as well as offered a potential to attract more clients.

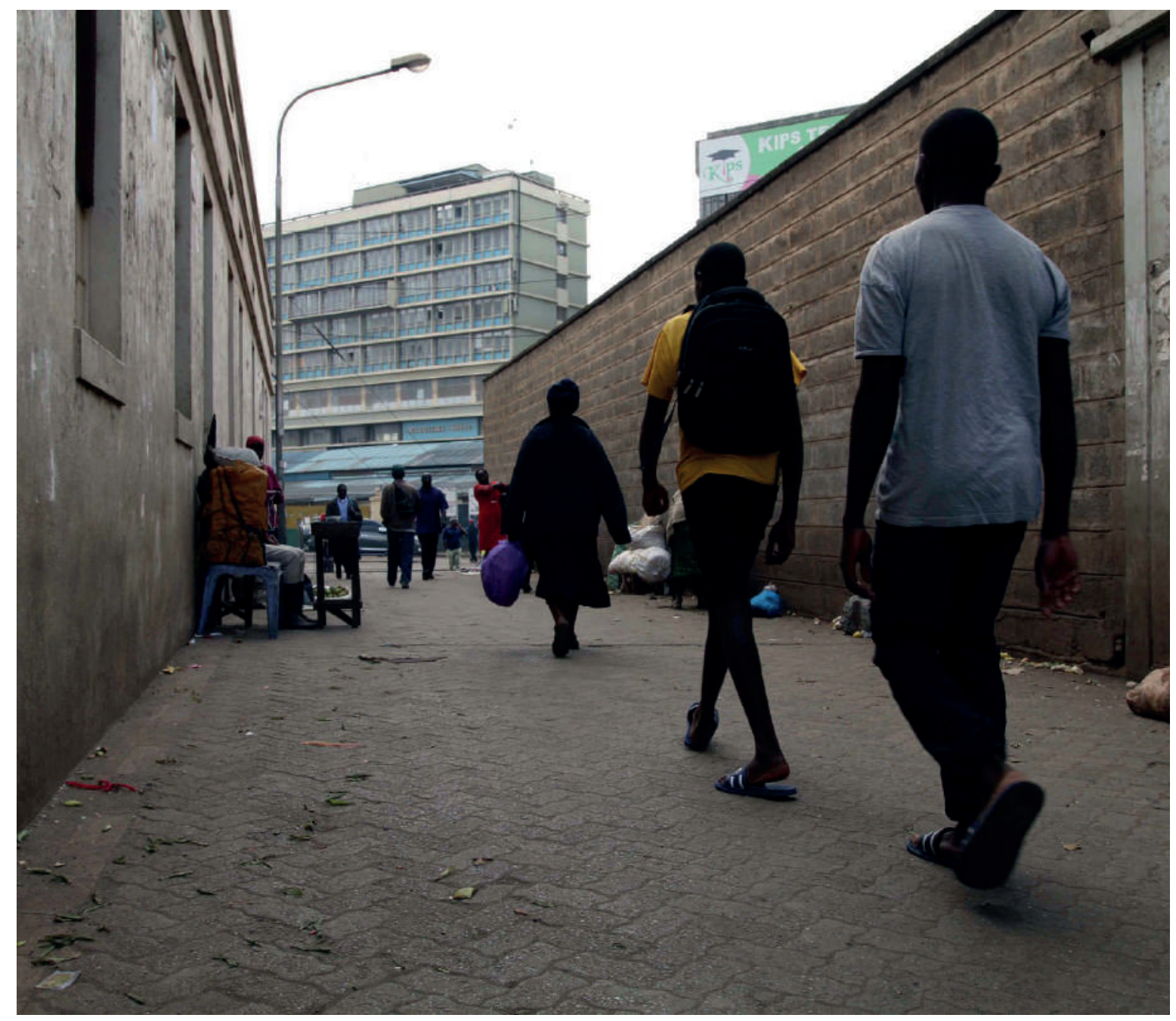

83 | The Journal of Public Space, 4(3), 2019 | ISSN 2206-9658 City Space Architecture / UN-Habitat 


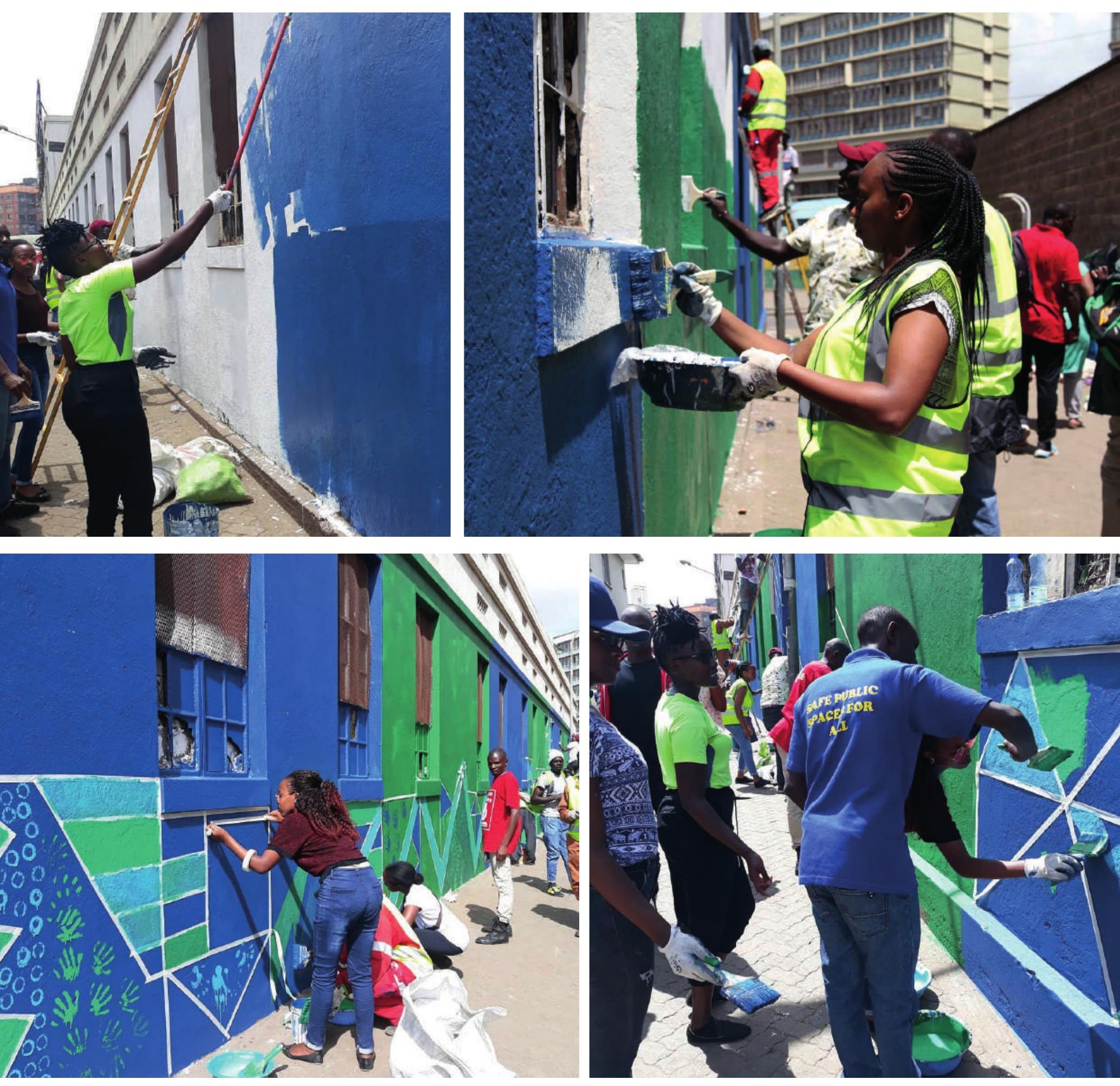




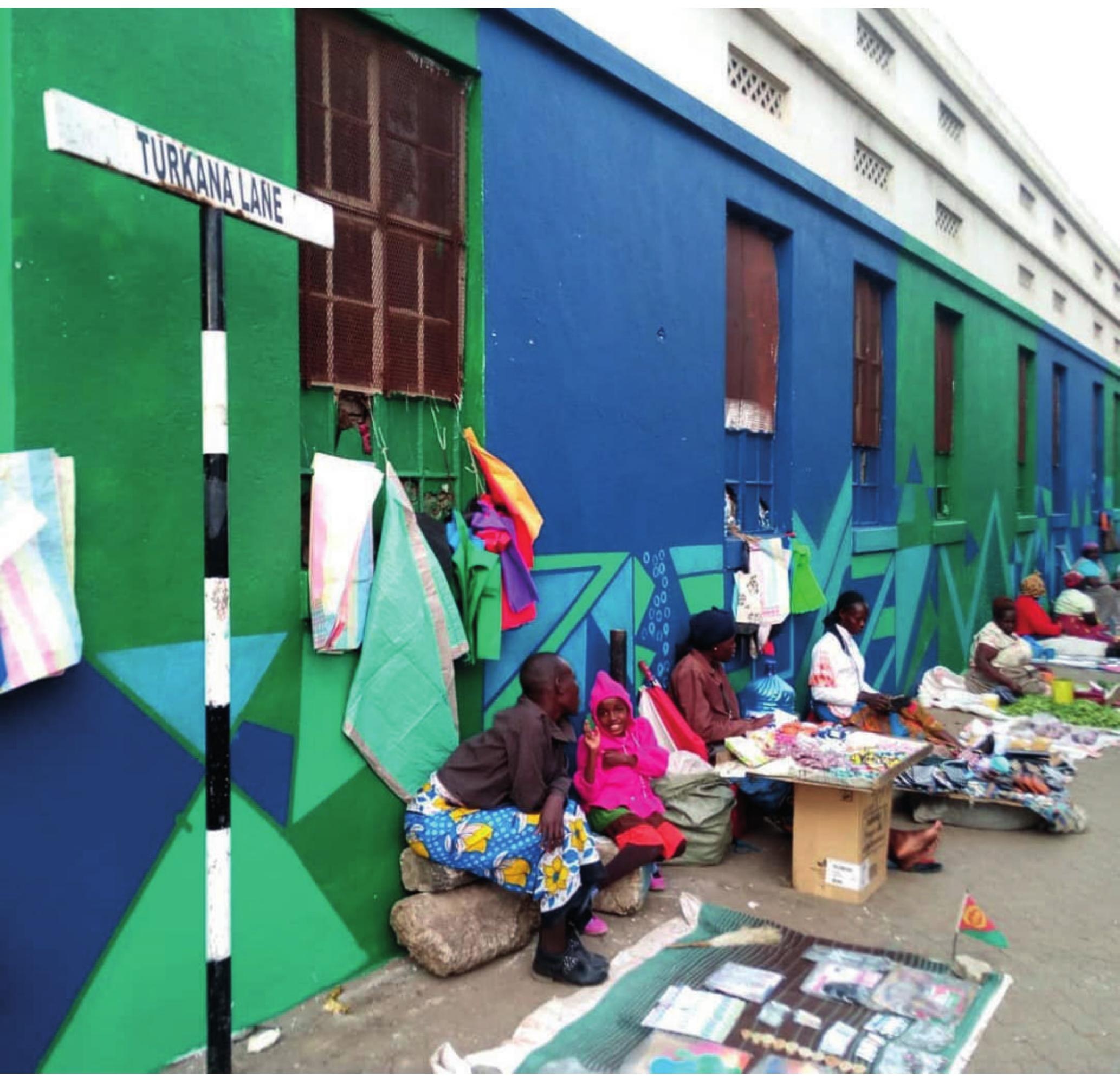

85 | The Journal of Public Space, 4(3), 2019 | ISSN 2206-9658 

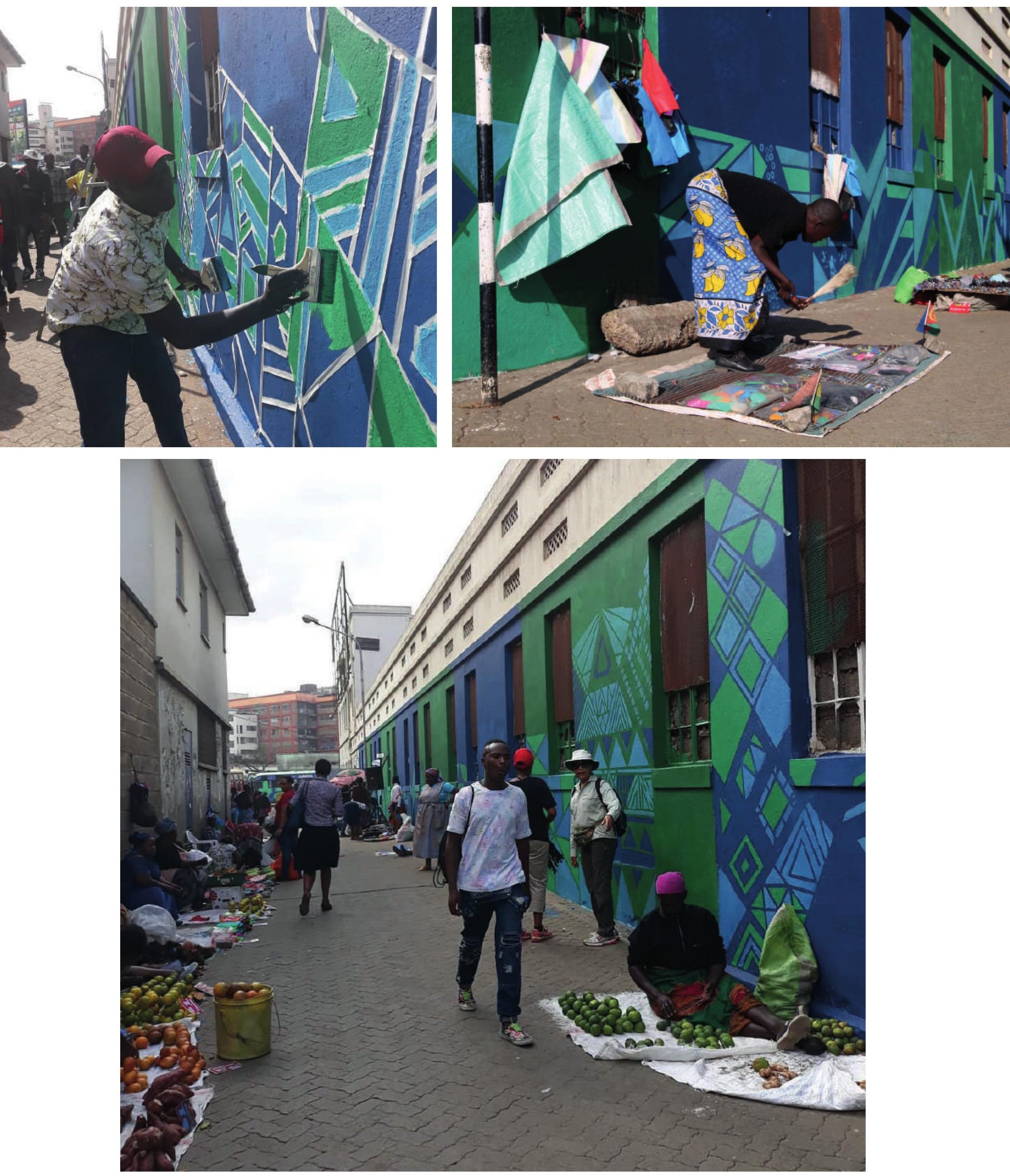

86 | The Journal of Public Space, 4(3), 2019 | ISSN 2206-9658

City Space Architecture / UN-Habitat 